\title{
PENGAJARAN BAHASA BERBASIS TUGAS (TASK BASED LANGUAGE TEACHING): PENDEKATAN YANG EFEKTIF DALAM PENGAJARAN BAHASA INGGRIS
}

\author{
Maria Cholifah ${ }^{1}$ \\ maria_cholifah@unikama.ac.id \\ Siane Herawati ${ }^{2}$ \\ siane.herawati@yahoo.com
}

\begin{abstract}
Abstrak
Tujuan dari artikel ini adalah untuk meninjau Task Based Language Teaching (TBLT) dalam Pengajaran Bahasa Inggris dan untuk menunjukkan efektivitas penggunaan TBLT dalam mengajar empat keterampilan bahasa. TBLT berfokus pada bahasa itu sendiri, akuisisi bahasa dan kinerja bahasa secara bersamaan. TBLT bertujuan meningkatkan kepercayaan diri dan antusiasme peserta didik. Mengajar melalui tugas dapat menciptakan kondisi belajar yang menguntungkan bagi pelajar bahasa Inggris karena kegiatannya menggunakan bahasa dan berfokus pada hasil kegiatan daripada hanya sekedar menggunakan bahasa Inggris saja. Artikel ini membahas ikhtisar TBLT, tujuan TBLT dan efektivitas penggunaan TBLT dalam mengajar empat keterampilan bahasa (mendengarkan, berbicara, membaca dan menulis).
\end{abstract}

Kata kunci: TBLT, empat keterampilan Bahasa, pengajaran bahasa Inggris

\begin{abstract}
This paper highlights the benefits of implementing Task-Based Language Teaching (TBLT) in teaching-learning of four skills of English. TBLT focuses on how English language is applied in accomplishing a certain task. TBLT also cultivates studenys' selfefficacy and enthusiasm in learning. Task-based activities create advantageous atmospheres in language learning since they focus on the outcomes of learning by maximizing the use of Engliah language. Furthermore, this paper discusses the essence, the purposes, and the effects of TBLT in enhancing students' four skills of English.
\end{abstract}

Keywords: TBLT, four skills of English, teaching-learning of English.

\section{LATAR BELAKANG}

Salah satu prinsip dalam Pengajaran Bahasa Inggris (English Language Teaching) saat ini adalah pendekatan dan metodologi yang patut diterapkan dalam proses belajar mengajar. Para peneliti dan guru bahasa Inggris setuju bahwa proses metodologis yang diterapkan harus membekali siswa dalam meningkatkan bahasa yang komunikatif secara substansial. Sehubungan dengan hal tersebut, guru bahasa Inggris harus memperbarui dan meningkatkan praktik mengajar mereka agar dapat meningkatkan proses belajar siswa dengan menggunakan metode dan pendekatan pengajaran baru yang berkaitan dengan Metode Komunikatif.

Hal yang menarik dari Instruksi Berbasis Tugas adalah potensi dari desain dan implementasi yang ditawarkan sesuai dengan kebutuhan komunikatif khususnya peserta didik. Dalam modul didaktik, tugas dilihat sebagai tolok ukur primer dari "input" pedagogik dalam pengajaran (Livingstone, 2012). 
Pengajaran Bahasa Berbasis Tugas (Task Based Language Teaching) telah dibuktikan oleh banyak peneliti sebagai pendekatan yang efektif untuk meningkatkan kemampuan dan keterampilan bahasa Inggris siswa. TBLT menekankan pada pendekatan tugas dan makna, tetapi tidak menghilangkan aspek tata bahasa dalam proses belajar mengajar.

\section{TUJUAN}

Tujuan artikel ini adalah untuk meninjau Pengajaran Bahasa Berbasis Tugas dalam pengajaran bahasa Inggris, dimulai dari perspektif historis TBLT, definisi dan tujuan TBLT, dan kemudian menunjukkan efektivitas penggunaan TBLT dalam mengajarkan empat keterampilan bahasa (menyimak, berbicara, membaca, dan menulis)

\section{HASIL}

\subsection{Perspektif Historis TBLT}

Selama 1980-an, Communicative Language Teaching (Pengajaran Bahasa Komunikatif) dominan di bidang Second Language Acquisition (Akuisisi Bahasa Kedua). Ellis (2003) berpendapat bahwa CLT secara tradisional menggunakan prosedur Present-Practice-Produce (PPP) terutama diarahkan pada bentuk linguistik dari bahasa target. Willis (1996) menyatakan bahwa presentasi pada satu titik tata bahasa atau fungsi, mempraktekkan aturan atau pola yang baru dipahami (latihan latihan, praktik dialog), dan produksi bahasa yang relatif bebas dalam konteks yang lebih luas dapat mengkonsolidasi apa yang telah dipresentasikan dan dipraktikkan, seperti sebagai tugas komunikasi atau aktivitas bermain peran.

Namun, pendekatan PPP memiliki kekurangan (Willis, 1996; Skehan, 1996; Ellis, 2003). Willis (1996: 135) menunjukkan bahwa "produksi" tidak terlalu sering dicapai di luar kelas: Pelajar sering gagal saat berkomunikasi (siswa tidak berkomunikasi sama sekali, atau siswa berkomunikasi tetapi tidak kurang baik) dengan penutur asli. Skehan (1996) juga berpendapat bahwa siswa tidak belajar apa yang diajarkan dalam urutan yang sama seperti yang diajarkan, sehingga presentasi, praktik, dan produksi materi tidak selalu sejalan. Ellis (2003) merangkum dua alasan untuk hasil ini: Pertama, penelitian di bidang SLA telah menunjukkan bahwa peserta didik tidak memperoleh bahasa dengan cara yang sama seperti yang sering diajarkan, dimana presentasi diikuti oleh praktik secara terkontrol dan kemudian produksi (model instruksi PPP); Kedua, peserta didik mengambil serangkaian tahap transisi yang tidak termasuk dalam PPP untuk memperoleh fitur tata bahasa tertentu.

Tabel 1 Ruang kelas tradisional dan ruang kelas TBLT (Nunan, 2005)

\begin{tabular}{ll}
\hline $\begin{array}{l}\text { Pedagogi tradisional yang berfokus } \\
\text { pada bentuk }\end{array}$ & Kelas TBLT \\
\hline - Struktur wacana yang kaku & - Struktur wacana fleksibel \\
- Guru mengontrol pengembangan topik & - Siswa mampu mengendalikan \\
- Guru mengatur pengambilan giliran & perkembangan topik \\
- Guru tahu apa jawabannya & - Pengambilan giliran diatur bersama \\
- Peran siswa merespons dan melakukan & - Guru tidak tahu apa jawabannya \\
rentang terbatas fungsi bahasa & - Siswa memulai dan merespons peran \\
- Sedikit bernegosiasi makna & dan melakukan berbagai fungsi
\end{tabular}


- Scaffolding untuk memungkinkan siswa menghasilkan kalimat yang benar

- Umpan balik yang berfokus pada bentuk gema bahasa

- Lebih banyak bernegosiasi makna

- Scaffolding untuk memungkinkan siswa mengatakan apa yang ingin mereka katakan

- Umpan balik yang berfokus pada konten pengulangan

Meskipun perbedaan ini tidak selalu berhasil, akan tetapi sangat membantu untuk memahami seperti apa ruang kelas TBLT. Pada Tabel 1 perbedaan antara ruang kelas tradisional dan ruang kelas TBLT ini memberi pemahaman kepada para guru bagaimana TBLT berbeda dari ruang kelas tradisional.

Konsep inti TBLT adalah tugas. Definisi tugas telah berkembang selama 20 tahun terakhir melalui penelitian empiris dalam implementasi ruang kelas. Nunan (2004: 4) mengatakan, "Suatu tugas adalah karya yang melibatkan peserta didik dalam memahami, memanipulasi, memproduksi, atau berinteraksi dalam bahasa target, sementara perhatian mereka difokuskan pada bagaimana memobilisasi pengetahuan tata bahasa mereka untuk mengekspresikan makna, dan tujuannya adalah untuk menyampaikan makna daripada memanipulasi bentuk. Tugas harus memiliki kelengkapan, dilakukan secara mandiri sebagai tindakan komunikatif dalam diri siswa".

Williams dan Burden (1997: 168) mengklaim bahwa tugas adalah kegiatan yang melibatkan peserta didik dalam proses belajar bahasa. N.S. Prabhu, (1987: 24) menekankan bahwa ini adalah kegiatan yang mengharuskan peserta didik untuk mencapai hasil dari informasi yang diberikan melalui beberapa proses pemikiran dan yang memungkinkan guru untuk mengontrol dan mengatur proses yang dianggap sebagai tugas. 'Tugas' didefinisikan oleh Willis (1996) sebagai kegiatan di mana bahasa target digunakan oleh peserta didik secara komunikatif untuk mencapai suatu hasil.

Berdasarkan definisi tersebut, setiap tugas dapat ditampilkan yang mencerminkan tiga aspek proses, partisipasi dan konten. Proses berarti apa yang dilalui guru dan peserta didik; Partisipasi kelas berkaitan dengan siapa peserta didik bekerja dalam proses. Konten adalah sesuatu yang menjadi fokus peserta didik (Littlejohn, 1998).

Skehan (1998) mensintesis karakteristik tugas diantaranya (1) Makna merupakan unsur utama; (2) Peserta didik tidak diberikan kesempatan untuk mengulang; (3) Suatu tugas memiliki beberapa koneksi ke dunia nyata; (4) Penyelesaian tugas memiliki beberapa prioritas; dan (5) Hasil penilaian diambil dari nilai tugas.

Pengajaran Bahasa Berbasis Tugas merupakan pendekatan yang menawarkan siswa untuk aktif terlibat dalam komunikasi untuk mencapai tujuan atau menyelesaikan tugas menggunakan bahasa. Pendekatan ini pertama kali dikembangkan oleh N.S. Prabhu di Bangalore, India Selatan. Menurut Prabhu, siswa dapat belajar lebih efisien ketika mereka lebih fokus pada tugas daripada bahasa yang mereka gunakan. TBLT memungkinkan proses pembelajaran melalui tugas yang harus dilakukan peserta didik atau masalah yang harus mereka selesaikan. (Harmer, 2007: 71).

Definisi lain yang dikemukakan oleh Larsen-Freeman (2000: 114), "Pengajaran bahasa berbasis tugas adalah sebuah pendekatan yang berusaha memberikan konteks 
alami kepada siswa untuk penggunaan bahasa. Ketika pelajar menyelesaikan tugas, mereka memiliki banyak kesempatan untuk berinteraksi. Interaksi semacam itu dianggap memfasilitasi penguasaan bahasa karena pembelajar harus bekerja untuk saling memahami dan mengekspresikan makna".

Menurut Willis (1996: 35-6) pengajaran bahasa berbasis tugas memiliki tujuan, yaitu:

1. Memberikan rasa percaya diri peserta didik dalam mencoba bahasa apa pun yang mereka ketahui;

2. Memberikan peserta didik pengalaman interaksi spontan;

3. Memberikan peserta didik kesempatan untuk mendapat manfaat dari memperhatikan bagaimana orang lain mengekspresikan makna yang serupa;

4. Memberikan kesempatan kepada peserta didik untuk bernegosiasi untuk berbicara;

5. Melibatkan peserta didik dalam menggunakan bahasa secara sengaja dan kooperatif;

6. Membuat peserta didik berpartisipasi dalam interaksi yang lengkap, bukan hanya kalimat satu kali;

7. Memberikan kesempatan kepada peserta didik untuk mencoba strategi komunikasi; dan

8. Mengembangkan kepercayaan diri peserta didik bahwa mereka dapat mencapai tujuan komunikatif.

Skehan (1996) dan Carless (2009) menjelaskan kelebihan dan kekurangan pengajaran bahasa berbasis tugas. Kelebihan tersebut adalah berfokus pada pembuatan makna dalam kehidupan nyata bersama dengan kinerja tugas yang otentik dan akurat. Sedangakn kelemahan TBLT yaitu mengakomodasi tugas yang lebih fleksibel untuk pengajaran komunikatif dan pedagogi bahasa (Hu, 2013). Peran yang dilakukan oleh pembelajar bahasa di TBLT dilabeli sebagai: peserta, pengambil risiko, pendengar/pembicara, pendongeng, inovator dan sequencer. Mereka berpartisipasi dalam kerja kelompok selama siklus tugas untuk pengembangan L2 yang sukses.

Unit dasar pelajaran di kelas TBLT adalah tugas dan berbagai tugas dirancang untuk memfasilitasi peserta didik dengan situasi komunikatif kehidupan nyata yang memungkinkan mereka menjadi komunikator nyata dari bahasa target. Pendekatan TBLT berpusat pada peserta didik, didasarkan pada sekolah pembelajaran konstruktivis dan guru berperan sebagai fasilitator dari interaksi komunikatif di antara peserta didik (Ellis, 2009). Selama TBLT siswa memainkan peran dinamis dalam seluruh proses pembelajaran bahasa saat ia mengambil bagian aktif dalam kegiatan interaktif dan komunikatif di sepanjang siklus kinerja tugas untuk mencapai hasil (Prabhu, 1987; Bygate et al., 2001; Skehan, 1998; Robinson, 2011; Ellis, 2003). Samuda dan Bygate (2008) mendefinisikan tugas sebagai kegiatan holistik yang melibatkan penggunaan bahasa untuk mencapai beberapa hasil nonlinguistik sambil memenuhi tantangan linguistik, dengan tujuan keseluruhan mempromosikan pembelajaran bahasa, melalui proses atau produk atau keduanya.

Nunan (2004) telah membedakan klasifikasi tugas sebagai tugas pedagogis dan tugas kehidupan nyata. Tugas pedagogis berarti aktivitas komunikatif yang dilakukan di kelas untuk mencapai hasil, tujuan dasar dari tugas pedagogis adalah latihan dunia nyata di sekitar. Tugas dunia nyata berarti komunikasi interaktif kehidupan nyata di luar kelas misalnya memesan tiket pesawat, wawancara kerja dan menjalin pertemanan baru.

\subsection{TBLT DALAM EMPAT KETERAMPILAN BAHASA}


Pentingnya belajar dan mengajar bahasa Inggris sebagai bahasa asing telah menciptakan percakapan sehari-hari untuk menerapkan strategi yang efektif untuk mengajar dan mempelajari empat keterampilan utama (mendengarkan, berbicara, membaca, menulis), karena keterampilan tersebut adalah tujuan akhir dalam belajar bahasa. Banyak kesulitan dan hambatan di jalan ini mengharuskan kita untuk revisi setiap hari dan menerapkan metode pengajaran baru untuk adaptasi yang lebih baik dan hasil yang unggul. Pentingnya pemahaman mendengarkan juga ditekankan oleh Spearritt (1962: 2) "Namun mendengarkan tidak diragukan lagi memainkan bagian penting dalam proses komunikasi. Berbagai penelitian telah menunjukkan bahwa, dalam hal jumlah waktu keempat keterampilan komunikasi digunakan, mendengarkan adalah keterampilan yang paling penting".

Mengenai hal ini, keterampilan mendengarkan telah menciptakan masalah dalam mengajar dan belajar pemahaman mendengarkan. Siswa sering mengeluh bahwa bahkan dengan praktik intensif, mereka tidak dapat memahami semua jenis teks yang diucapkan sepenuhnya. Gagasan praktik intensif berbeda dari tugas, di mana tugas yang efektif dapat memiliki hasil yang mendukung walaupun hanya melibatkan peserta didik dengan tugas sekali atau dua kali, kemudian memberikan mereka beberapa praktik yang disiapkan dan meminta mereka untuk melakukannya ratusan kali. Menyoroti pentingnya mendengarkan berbasis tugas, kita dapat merujuk pada ide Ellis (2003: 65) yaitu "... penelitian mendengarkan berdasarkan tugas telah berkontribusi pada pemahaman kita tentang bagaimana properti input spesifik mempengaruhi pemahaman dan penguasaan bahasa".

Melalui penelitian berbeda yang diterbitkan dalam konteks yang berbeda, seperti India oleh Mohanraj (1994), Turki oleh Tavil (2010), dan bahasa Perancis oleh Graham (2005), tersirat bahwa instruksi berbasis tugas dapat meningkatkan kemampuan pemahaman mendengarkan secara bermakna. Namun, instruksi berbasis tugas, oleh semua pendukungnya, belum memuaskan beberapa orang lain tentang metodologinya. Mengenai hal ini, kesenjangan sebenarnya adalah apa yang komentar Ellis, (2003: 79) "Namun, kurikulum berbasis tugas masih melibatkan pengambilan keputusan tentang konten (yaitu, tugas apa yang harus dimasukkan dalam silabus) dan metodologi (yaitu, bagaimana tugas akan digunakan di kelas), oleh karena itu, penting untuk menjaga perbedaan dalam diskusi pengajaran berbasis tugas”. Melanjutkan pandangan modifikasi ini, penelitian ini mempertimbangkan tugas berbasis video untuk mengajarkan pemahaman mendengarkan. Warschauer (2002: 4) juga berkomentar, "Pengajaran dan pembelajaran bahasa komunikatif telah membuktikan bahwa penggunaan video dapat mempercepat pemahaman peserta didik hingga penggunaan bahasa yang sebenarnya".

Sarani, Behtash dan Arani (2014) melakukan penelitian "Pengaruh Tugas Berbasis Video dalam Mendengarkan Pemahaman Pembelajar EFL (English as a Foreign Language) Pra-Menengah Iran". Tujuan di balik penelitian ini adalah untuk menyelidiki keefektifan instruksi tugas berbasis video pada kemampuan mendengar bagi peserta didik EFL pra-menengah Iran. Hal ini bermaksud untuk melihat apakah ada efek yang patut dicatat dari instruksi tugas berbasis video pada peningkatan kemampuan pemahaman mendengar bagi peserta didik EFL. Hasil penelitian menunjukkan bahwa mengajar menyimak berdasarkan tugas-tugas berbasis video memiliki efek signifikan pada pemahaman mendengarkan peserta didik dalam mewujudkan dan memahami bahasa otentik lebih efektif. 
Vandergrift (2004: 10) mengatakan, "Literatur terbaru tentang instruksi mendengarkan L2 menunjukkan bahwa siswa dapat mengambil manfaat dari pendekatan di mana strategi diajarkan secara terpadu". Studi tersebut dalam menguji hipotesis nol membuktikan bahwa pendekatan terpadu ini dapat dicapai dengan menginstruksikan pemahaman menyimak melalui tugas-tugas berbasis video. Oleh karena itu, hipotesis bahwa instruksi berbasis tugas berdasarkan tugas-tugas berbasis video tidak memiliki efek yang signifikan pada peningkatan kemampuan pemahaman mendengarkan peserta didik EFL pra-menengah Iran sangat ditolak. Ini berarti bahwa instruksi berdasarkan tugas berbasis video memberikan siswa perkembangan yang baik dalam kemampuan pemahaman mendengarkan.

Albino (2017) melakukan penelitian "Meningkatkan Kelancaran Berbicara dalam Pendekatan Pengajaran Bahasa Berbasis Tugas: Studi Kasus Pembelajar EFL di PUNIV-Cazenga". Penelitian ini merupakan upaya untuk menilai bagaimana pelajar bahasa Inggris sebagai bahasa asing (EFL) meningkatkan kefasihan berbicara mereka dalam pendekatan pengajaran bahasa berbasis tugas (TBLT) yang digunakan dengan pelajar kelas sembilan di PUNIV-Cazenga, sebuah sekolah menengah di Luanda.

Hasil dari penelitian menunjukkan bahwa pendekatan tersebut dapat digunakan dengan sukses di PUNIV-Cazenga pada khususnya, dan dalam konteks Angola pada umumnya. Setelah diajarkan dengan pendekatan TBLT, peserta didik merasa terdorong untuk berbicara, dan dorongan itu dapat dianggap efektid dalam membuat peserta didik berbicara pada situasi apa pun. Bahkan, peserta didik percaya bahwa mereka siap untuk berkomunikasi apa pun di luar kelas. Fokus pada makna dan bentuk, dalam pendekatan TBLT, dilihat oleh peserta didik sebagai keuntungan dari sudut pandang ujian mereka di sekolah. Namun, mereka menyarankan keseimbangan antara pembelajaran bentukbentuk bahasa dan praktik kelancaran berbicara. Satu komentar penting dibuat oleh pelajar yang menyarankan bahwa semua guru di PUNIV-Cazenga harus mengadopsi pendekatan TBLT.

Pendapat pembelajar tentang kegunaan pendekatan TBLT bukanlah hal baru. Dalam studi mereka, di mana mereka bertujuan untuk membantu peserta didik EFL dalam memaksimalkan penggunaan bahasa target dan mendapatkan kelancaran berbicara, Buriro dan Hayat (2010) menemukan bahwa peserta didik puas dengan pendekatan tersebut. Temuan pada pendapat pelajar dalam penelitian ini, secara positif mereplikasi temuan dalam yang sebelumnya. Dengan demikian, temuan pada pendapat peserta didik dan transkrip dari deskripsi gambar memiliki implikasi yang cukup besar untuk praktik mengajar dan penelitian di masa depan.

Penelitian lain yang dilakukan oleh Irfan (2017) "Pengaruh Pengajaran Bahasa Berbasis Tugas pada Pemahaman Membaca Siswa". Tujuan dari penelitian ini adalah untuk mengetahui apakah ada peningkatan yang signifikan pada siswa yang mengajar pemahaman membaca menggunakan Pengajaran Bahasa Berbasis Tugas dan yang diajarkan menggunakan Metode Penerjemahan Grammar (Grammar Translation Method). Ditemukan bahwa ada perbedaan yang signifikan antara kedua kelompok.

Banyak peneliti dalam penelitian sebelumnya telah menunjukkan persetujuan dengan temuan penelitian ini. Mulyono (2008) menyatakan bahwa siswa yang diajar dengan menggunakan TBLT mendapat hasil yang lebih baik dalam pemahaman membaca. Studi ini juga mendukung temuan Poorahmadi (2012), dan Hayati dan Jalilifar (2010) yang menemukan bahwa TBLT sangat efektif dalam meningkatkan kemampuan membaca pemahaman siswa EFL. Hasil penelitian ini juga sesuai dengan 
Iranmehr, Erfani, dan Davari (2011) yang mendukung pelaksanaan tugas dan menyajikan manfaat yang signifikan dari pengajaran menggunakan TBLT.

Ahmed dan Bidin (2016) melakukan penelitian "Pengaruh Pengajaran Bahasa Berbasis Tugas pada Keterampilan Menulis Pembelajar EFL di Malaysia". Tujuan dari penelitian ini adalah untuk mengukur efektivitas Pengajaran Bahasa Berbasis Tugas dalam menigkatkan keterampilan menulis sarjana universitas yang belajar bahasa Inggris di pusat-pusat bahasa di lembaga-lembaga sektor publik tingkat tersier di Malaysia.

Tidak ada perbedaan yang signifikan untuk menandai peningkatan skor kelompok kontrol dibandingkan selama pretest dan posttest dalam keterampilan menulis mereka. Hasil penelitian menunjukkan bahwa tidak ada perbedaan yang signifikan dalam skor pretest dan skor posttest dari kinerja L2 dalam kelompok kontrol tetapi dalam kasus kelompok eksperimen ada signifikansi statistik dalam skor indikator kinerja L2, kompleksitas, kelancaran dan akurasi.

Beberapa siswa berpendapat TBLT sebagai cara belajar dan mengajar yang menarik. Hal ini diperjelas bahwa sebagian besar umpan balik siswa adalah mendukung efektivitas TBLT dan persepsi mereka cenderung setuju dan sangat setuju jika pengajaran Bahasa Inggris menggunakan pendekatan TBLT. Hal tersebut juga menunjukkan bahwa siswa menyukai pengajaran dengan menggunakan pendekatan TBLT dan bukti bahwa TBLT adalah pendekatan pengajaran bahasa yang berpusat pada peserta didik.

\section{KESIMPULAN}

Peneliti telah mencoba meninjau TBLT mulai dari sejarah, definisi, karakteristik, tujuan, dan efektivitas TBLT dalam pengajaran Bahasa Inggris. TBLT sejauh ini merupakan pendekatan yang efektif untuk diterapkan dalam pengajaran empat keterampilan bahasa (menyimak, berbicara, membaca dan menulis). Namun TBLT masih memiliki kelemahan, TBLT merupakan pendekatan yang lebih fleksibel untuk pengajaran komunikasi dan pedagogi bahasa. Hal ini merupakan tantangan bagi para guru dan peneliti bahasa Inggris untuk menemukan metodologi terbaik dalam mengajar dengan menggunakan TBLT.

Diharapkan para guru dan peneliti dapat memodifikasi atau menggabungkan pendekatan dalam pengajaran, tidak hanya dengan menggunakan TBLT tetapi juga pendekatan lainnya. Dengan demikian siswa akan mendapatkan cara terbaik dalam proses belajar mengajar.

\section{REFERENSI}

Ahmed and Bidin. 2016. The Effect of Task Based Language Teaching on Writing Skills of EFL Learners in Malaysia. Open Journal of Modern Linguistics, 6, 207-218

Albino, 2017. Improving Speaking Fluency in a Task-Based Language Teaching Approach: The Case of EFL Learners at PUNIV-Cazenga. SAGE. Open AprilJune 2017: 1-11 
Buriro, G. A., \& Hayat, T. 2010. Task-based Learning: An in-Class ELT Experiment. Journal of Educational Research, 13, 121-132.

Bygate, M. et al. (Eds.). 2001. Researching Pedagogic Tasks: Second Language Learning, Teaching and Testing. Harlow: Longman.

Carless, D. 2009. Revisiting the TBLT versus PPP Debate: Voices from Hong Kong. Asian Journal of English Language Teaching, 19, 49-66.

Ellis, R. 2003. Task-based Language Learning and Teaching. Oxford University Press.

Ellis, R. 2009. Task-Based Language Teaching: Sorting out the Misunderstandings. International Journal of Applied Linguistics, 19, 221-246.

Graham, S. 2005. Listening comprehension: The learner's perspective. System, 34(2), 156-182.

Harmer, Jeremy. 2007. The Practice of English Language Teaching. Ashford Colour Press

Hayati, M., \& Jalilifar, A. 2010. Task-Based Teaching of Micro-Skills in an EAP Situation. Iranian International ESP Journal, 2(2), 49-66.

Hu, R. 2013. Task Based Language Teaching: Responses from Chinese Teachers of English. TESL-EJ, 16, 1-21.

Iranmehr, A., Erfani, S. M., \& Davari, H. 2011. Integrating Task-Based Instruction as an Alternative Approach in Teaching Reading Comprehension in English for special purposes. Theory and Practice in Language Studies, 1(2), 142-148.

Irfan. 2017. The Effect of Task-Based Language Teaching on Students' Reading Comprehension. English Education Journal (EEJ), 8(1), 113-126

Larsen-Freeman, Diane. 2000. Techniques and Principles in Language Teaching. Oxford University Press.

Livingstone. 2012. Task-Based Language Teaching as a Suitable Didactic Method for the Teaching and Learning of Second and Foreign Languages. Baraton Interdisplinary Research Journal, 2(2), 63 - 75

Mohanraj, J. 1994. Developing Listening Comprehension Using Easily Available Resources. English Teaching Forum, Oct. 1994, 40.

Mulyono, S. 2008. Pengaruh Motiasi Belajar dan Task Based Language Teaching terhadap Hasil Belajar Membaca Bahasa Inggris pada Siswa Kelas XI SMAN Sumbawa Besar dan SMAN 1 Lunvuk. (Unpublished Master's thesis). Universitas PGRI Adi Buana, Surabaya. 
Nunan, D. 2004. Task-based Language Teaching. Cambridge: Cambridge University Press.

Nunan, D. 2005. Important Tasks of English Education: Asia-wide and beyond. Asian EFL Journal, 7(3).

Poorahmadi, M. 2012. Investigating the Efficiency of Task-Based Instruction in Improving Reading Comprehension Ability. The Journal of Language and Translation, 3(1), 29-36.

Prabhu, N. S. 1987. Second Language Pedagogy. Oxford: Oxford University Press.

Robinson, P. 2011. Task-Based Language Learning. Ann Arbor, MI: Language Learning Research Club, University of Michigan.

Samuda, V., \& Bygate, M. 2008. Tasks in Second Language Learning. Basingstoke: Palgrave.

Sarani, Behtash and Arani. 2014. The Effect of Video-Based Tasks in Listening Comprehension of Iranian Pre-intermediate EFL Learners. Gist Education and Learning Research Journal, 8. pp. 29-47.

Skehan, P. 1996. Second Language Acquisition Research and Task-based Instruction. In: Willis, J. \& Willis, D. (Ed.). Challenge and change in language teaching. Oxford: Heinemann.

Skehan, P. 1998. A Cognitive Approach to Language Learning. Oxford: Oxford University Press.

Spearritt, D. 1962. Listening Comprehension: A Factorial Analysis. Melbourne: G. W. Green \& Sons.

Tavil, Z. M. 2010. Integrating Listening and Speaking Skills to Facilitate English. Procedia - Social and Behavioral Sciences, 9, 765-770.

Vandergrift, L. 2004. Learning to Listen or Listening to Learn. Annual Review of Applied Linguistics, 24, 3-25.

Warschauer, M. 2002. A Developmental Perspective on Technology in Language Education. TESOL Quarterly, 36(3), 453-475.

William, M. and R.L. Burden. 1997. Psychology for Language Teachers: A Social Constructivist Approach. Cambridge: Cambridge University Press.

Willis, J. 1996. A Framework for Task-Based Learning. Harlow: Longman 